\title{
Migration Governance in South America: \\ Regional Approaches versus National Laws
}

\author{
Victoria Finn ${ }^{1}$ \\ Cristián Doña Reveco ${ }^{2}$ \\ Mayra Feddersen ${ }^{3}$
}

\section{Citation:}

Finn, Victoria, Cristián Doña Reveco, and Mayra Feddersen. (2019). Migration Governance in South America: Regional Approaches versus National Laws. In The Dynamics of Regional Migration Governance, A. Geddes, M. V. Espinoza, L. Hadj-Abdou, and L. Brumat (Eds.). Edward Elgar Publishing. doi.org/10.4337/9781788119948.00008.

This is a pre-print, but accepted, peer-reviewed chapter. The final version is in The Dynamics of Regional Migration Governance (2019), as the above citation indicates. The material cannot be used for any other purpose without further permission of the publisher and is for private use only.

\begin{abstract}
\footnotetext{
${ }^{1}$ Universidad Diego Portales, Leiden University; vickijfinn@gmail.com

${ }^{2}$ University of Nebraska-Omaha

${ }^{3}$ Universidad Adolfo Ibáñez
}

Regional Consultative Processes (RCPs) have become the standard for multilateral migration policy discussion over the last two decades. RCPs are geographically bounded, non-binding meetings organized voluntarily by states and promoted by international organizations. Our chapter contributes to accumulating knowledge regarding the migration governance role of RCPs by 
investigating the South American Conference on Migration (CSM). We conduct a thematic analysis of CSM documents from its first annual meeting in 2000 until 2017 to find the most salient themes. We then examine migration-related legislation to uncover to what extent national laws incorporate regional discussion and accords. We find that although multilateral cooperation has created a set of common standards and practices, their domestic incorporation remains uneven. This chapter sheds light on the synergy between regional-level priorities and national-level laws, revealing a limitation of regional migration governance.

Key words: migration governance, policy coordination, human rights, South American Conference on Migration, Regional Consultative Processes

\section{INTRODUCTION}

This chapter shows that multilateral cooperation cannot only contribute to governing migration through developing common practices and shared discourses but can also influence migration- related national legislations. Our case study is the South American Conference on Migration $(\mathrm{CSM})^{1}$ from its establishment in 2000 until 2017. Since its inception, the CSM, alongside other regional institutions, has prioritized human rights and policy coordination. We examine how these themes have been built into the CSM in order to focus on our main question: to what extent are human rights and other CSM topics reflected in its Member States' migration laws? To answer this, we conduct two analyses. First, we determine the main themes within the debates of the CSM from the last 17 years. Second, we search for the CSM themes within national migration legislations in the 12 South American countries over the same period to highlight where regional topics overlap or contrast with national laws. We find that the agreements reached at the CSM have had selected effects on recent migration-related legislation across the continent. 
Based on this analysis, we suggest that while we can observe a positive effect of regional migration governance on the development of national-level migration laws, there are limits to the synergy between these two levels of migration governance.

Immigration laws are inherently contradictory. According to Hampshire (2013), when attempting to control immigration flows, states face tension between two opposing sides: one includes the security of the territory along with understandings of nationhood, whereas the other reflects the necessity of economic accumulation and the government's institutional legitimacy, which is based on promoting policies that respect the formal conditions of democracy and freedom (Boswell 2007; Hampshire 2013). Migration policies controlling flows of people similar to trade and investment policies — involve a balance of necessity and possible risk, thus states regulate them but cannot stop them (Hollifield 2000). Migration flows have induced intense political conflicts, which can lead to enacting and implementing contradictory laws and policies, simultaneously restricting immigration flows whilst also facilitating accessibility (Hollifield et al. 2014). States have pushed for international cooperation as a viable solution to previous deadlock (Geiger and Pécoud 2014).

Geographic regions as a level of organisation may be a solution for migration governance. Regional integration as a process can be used to identify patterns of state cooperation (Söderbaum 2016). We know and understand why migration-related legislation can be contradictory at the state level (Hampshire 2013; Hollifield et al. 2014); in this chapter, we aim to show to what extent national laws contrast with or reflect regional approaches and discussion. The South American Conference on Migration and other similar spaces, known as Regional Consultative Processes (RCPs), are examples of regional initiatives. While before the 2000s there was little academic interest in RCPs (Geiger and Pécoud 2014; Börzel and Risse 2016), it is now a growing 
field of research (such as Hansen 2010; Harns 2013; Acosta and Freier 2018). In this context, analysing the outcomes of the South American Conference of Migration after more than a decade and a half of existence can produce insights yielding new information into the emergence, institutional design and effectiveness of other inter-regional spaces (Börzel 2016: 5).

Using a thematic analysis of publicly available CSM documents from 2000 to 2017, we pinpoint two recurring themes: ensuring migrants' human rights and coordinating migration policies. Prioritizing human rights is frequently emphasised in regional agreements and promises of action; yet, the CSM's non-binding nature does not ensure domestic legislative changes since enforcement, monitoring and sanctioning are absent. Using the same analysis for recent migration-related national legislations, we examine countries that have changed their laws between 2000 and 2017 to determine if they have incorporated these themes into new legislation. While we cannot claim regional discussion has directly caused national legislative changes, we can determine to what extent state legislation reflects or conflicts with salient CSM themes. Thus, using the case of the South American Conference on Migration, we argue that regional cooperation plays a role in migration governance, even though it faces limits regarding its effect on national-level migration legislation.

The following section describes our method of analysis and data sources. Section two concentrates on regional cooperation, including concepts of Latin American regionalism. The third section focuses on our region of interest, leading into our qualitative thematic analysis of documents from the CSM between 2000 and 2017. The fourth section discusses the extent to which regional interests are reflected in national laws in the 12 South American states. The conclusion summarizes this case's main contributions to our understanding of migration governance. 


\section{METHOD AND DATA SOURCES}

This chapter's method of analysis entails a qualitative thematic analysis in which we review regional-level documents from the annual CSM. Thematic analysis is a qualitative approach that uses a process of skimming, reading and interpretation to discover patterns within data (Fereday and Muir-Cochrane 2006; Bowen 2009). Themes surface from these patterns, which then become the categories for analysis. We do this to find the most salient topics as well as to comprehend how CSM participants discuss these themes. In other words, it is not only the frequency of a subject, but also the wording used around it, as well as how that wording develops over time.

We systematically examine the final written statements (declaraciones finales/oficiales) from each meeting. These documents are publicly available on the website of the Observatorio Sudamericano de Migraciones (CSM-OSUMI 2017), which is CSM's virtual space for information sharing and dissemination. The final documents are available for every meeting and represent the official position of the conference and of each Member State. We complemented our analysis by reviewing each Conference's main thematic focus, which have been labelled since 2009, as well as other signed agreements and selected documents, such as presentations or reports, also available from OSUMI. Moreover, the list of participants reveals that from the CSM's establishment in 2000 through to the fifth conference in 2004 , only ten of the 12 South American countries attended the meetings; Guyana and Suriname began participating intermittently from the sixth conference and permanently after the tenth. Government representatives, individuals from civil society, as well as international organizations (as observers) also frequently attend.

When comparing the regional-level developments in migration governance to national- 
level policies, we use the salient CSM themes as focal points to evaluate if domestic migration legislation reflects or contrasts with regional interests. We use the Organization of American States (OAS) Database of Migration Legislation in the Americas (MILEX 2018) as a source for most of the South American states' migration policies. MILEX contains an up-to-date collection of migration-related legislation for all the countries analysed, excepting Brazil, Ecuador and Venezuela. For the first, we use the official website of the Brazilian government. ${ }^{2}$ For the latter two, we use the International Labour Organization's NATLEX, an online database of national labour, social security and related human rights legislation (NATLEX 2018).

\section{REGIONAL MIGRATION GOVERNANCE}

Overarching global-level dynamics have proven challenging for migration governance, especially given the unpredictable shifts in migratory flows and directionality, varying types of migration, as well as specific political contexts (Betts and Kainz 2017). Contemporary migration flows, particularly within regions, pushed receiving states to evaluate how to handle emerging patterns (Heisler 1992; Hollifield 1992; Klekowski von Koppenfels 2001). International organisations and some major receiving nations responded by creating intergovernmental spaces for discussing migratory topics with the intention of then managing flows (Klekowski von Koppenfels 2001; IOM 2003; GCIM 2004; Domenech 2007; Hansen 2010; Harns 2013). These spaces, known as Regional Consultative Processes (RCPs), lie between the global and national levels. RCPs are voluntary informal governmental meetings for discussing migration in order to move beyond unilateral migration policy creation —although any agreements are non-binding (Estupiñán 2016; IOM 2018). They provide an open space for dialogue and are state-owned, designed and ruled, they have met more than once, and focus on mutual topics aligned with current migration needs (Klein Solomon 2005). Currently there are 
15 active (and three dormant) RCPs worldwide (IOM 2018).

The main drawback of RCPs is that although participants may influence fellow states' migration policymaking, the non-binding agreements imply no domestic commitment, nor carry enforceable punishment for those who fail to implement regional agreements. Another issue is the significant power differences that may exist between its members. The case of the 'Puebla Process' is a strong example since its members are Canada, the United States, Mexico and the Central American countries. In contrast, migration between countries of similar levels of development, such as those with South-South migration, face fewer international power dynamics, meaning sending and receiving nations are in a more balanced position to cooperate (Klein Solomon 2005). The de facto horizontality between South-South countries can favour multi-level migration governance since more balanced power relations can reduce cooperation costs.

While much research has been done on migration between North and South countries, the dynamics of South-South flows are gaining relevance since they comprise about 40 per cent of worldwide migration (Ratha and Shaw 2007; Campillo-Carrete 2013). South America is home to about five million migrants while more than eight million people have left the region to reside elsewhere (UNDESA 2017; Martínez and Orrego 2016). In this context, a better understanding of regional approaches to migration can provide a vantage point. This chapter is thus positioned to do just that: we approximate migration governance occurring within geographically close areas in the South that share overlapping interests, interdependence, networks and common challenges. $^{3}$

Latin America, and specifically South America, has developed its own variety of regionalism (Bianculli 2016). In these territories, states and non-state actors participate in a 
variety of regional organisations characterized by overlapping memberships, complementing (and at times competing) political, economic and social agendas (Bianculli 2016; Börzel and Risse 2016). Variety is mainly the result of fluctuating preferences and strategies in specific historical and political contexts (Bianculli 2016). Beginning in the 1960s, cooperation was for economic and trade purposes. Nevertheless, a lack of tangible results and the rise of military regimes changed these regional priorities. The 1990s signalled the rebirth of CAN (the Andean Community of Nations) and the creation of MERCOSUR (the Southern Common Market), associated with democratic restoration and structural adjustment programs. Member States perceived free trade as a strategy to gain autonomy and enhance the region's economic and political independence from the rest of the world (see Chapter 4). As Chapter 4 in this volume also shows, global and regional economic crises - coupled with a 'turn to the left' throughout the region-led to further changes in the 2000s to these initiatives. Newly elected governments sought alternative political, economic and development policies.

This 'post-hegemonic' or 'post-neoliberal' regionalism came with new preferences and economic interests. In parallel, policies such as human rights, the environment, and immigration gained increased relevance in regional discussions (Briceño-Ruiz and Ribeiro Hofmann 2015; Bianculli 2016). State participation in regional forums has contributed to the propagation of its main themes (Lavenex et al. 2016: 416). For instance, as a direct result of prior dictatorships, human rights became a recurrent theme in international regimes (Hafner-Burton 2012) and specifically in multilateral forums. In Latin America, Pevehouse (2016) highlighted how MERCOSUR included a protocol on human rights in 2005 and the Andean Community supported the jurisdiction of the Court of Justice to hear individual human rights claims against countries.

Despite isolated examples, there are few recent studies regarding the connection between 
regionalism and human rights (Pevehouse 2016). One way of assessing the level of regional integration is through states' absorption of human rights promoted at RCPs. By incorporating human rights language from international discussions into national statutes, state actors are indirectly changing the formulation and implementation of domestic policies. However, this depends on the relevance that governments give to this topic vis-à-vis other migration topics, such as securitisation. As the 'left turn' ends in South America, we are in a key position to assess the incorporation of human rights themes and other regional priorities in national migrationrelated legislation.

\section{MIGRATION RESPONSES IN SOUTH AMERICA}

Migration across the continent is strongly an intraregional phenomenon: 70 per cent of all migrants that live in a South American country were born in another South American country (UNDESA 2017; Martínez and Orrego 2016). The region comprises 12 nation states: Argentina, Bolivia, Brazil, Chile, Colombia, Ecuador, Guyana, Paraguay, Peru, Suriname, Uruguay and Venezuela. Much intraregional migration here is also border migration: for instance, 40 per cent of all South American migrants in Argentina are from Paraguay, as are Peruvians in Chile (50 per cent), Bolivians and Brazilians in Paraguay (22 per cent), Colombians in Venezuela (88 per cent) and Venezuelans in Colombia (62 per cent). At the same time, intraregional South American migration has continued to grow about 10 per cent each decade, from 24 per cent in 1970 to 63 per cent in 2010 and will likely continue to increase in the coming years (UNDESA 2017; Martínez and Orrego 2016). Unexpected flows have also entered the scene, such as from Spain to Ecuador and from Haiti to Brazil.

For economic and labour migrants, there are several bi-national agreements, as well as 
the MERCOSUR Residence Agreement, which liberalizes the residence for two years for South American nationals. Within the region, there have also been discussions on moving towards a South American citizenship (UNASUR 2018; Ramírez 2016). Open borders throughout the area would eliminate regional undocumented labour migration since work visas and additional paperwork would become obsolete; this has become a reality where the MERCOSUR Residence Agreement is enforced. More specifically, intraregional circular migration has the potential to generate benefits and development opportunities (Hugo 2013). This is not a new idea in the region: in 1977, the Andean Pact developed the Andean Labour Migration Instrument to facilitate the circular movement of workers between Andean nations (Gurrieri 2005; Martínez and Stang 2006). Compared to the EU, South America has distinct advantages. South America for the most part shares a common language, close cultural backgrounds, and has ethnic and historical connections (Pellegrino 2007; for differences between the South American and EU cases, see Acosta 2016 and Chapter 4 in this volume). ${ }^{4}$ With lower language barriers, human capital rich with diverse skill sets of all levels can be transferred throughout regional labour markets. More mobile workers offer further economic gains for both sending and receiving nations, including supporting development through remittances and 'brain circulation' (O’Neil 2003; Constant et al. 2012).

Beyond labour migrants, the region has also reached considerable agreements regarding forced migration. For instance, the Cartagena Declaration of Refugees of 1984, agreed upon by ten South American states, demonstrated regional solidarity on the issue of displaced persons (Esthimer 2016). Following, two other influential regional agreements on refugees are the Mexico Declaration and Plan of Action to Strengthen International Protection of Refugees in Latin America (2004) and the Brazil Declaration and Plan of Action (2014). The latter continues 
to be applied and was extended to non-regional refugees, such as from Syria.

To discuss various migration topics and align political migration strategies, the 12 countries in 2000 convened the CSM. With the exception of 2005, they have met annually to participate in this Regional Consultative Process (RCP). The CSM was founded by the South American governments in 1999 with the underlying assumption, similar to other integration processes, that integration was beneficial for the region. As with most RCPs, the CSM first began without a formal document or treaty defining its rules for operation. Its recurrent practices since the 2003 meeting, however, demonstrate a high level of institutionalisation. ${ }^{5}$ Each year, the meeting location rotates and a country assumes the presidency pro-tempore, responsible for organizing the main meeting, a preparatory 'intersessional' meeting midyear, and the conference agenda, among other functions. ${ }^{6}$

As of 2017, the CSM is a central component of the region's approach to migration governance. Coexisting with other economic, social and political integration schemes, the CSM documents reveal strong and continued support for CAN, MERCOSUR and UNASUR stances and actions, particularly regarding regional and subregional integration, including South American citizenship. ${ }^{7} \mathrm{CSM}$ participants benefit from participating in non-binding discussions on migration topics since they share knowledge and lessons learned. It thus creates a space 'to meet, maintain and exchange successful policy and migration management experiences' ${ }^{8}$ The goal behind this space - following the IOM's motto-is to manage migration for the benefit of all. What specific 'benefits' are meant, however, is unclear in CSM documents. Through our thematic analysis of these documents, we found two main repeated topics discussed over the years: ensuring migrants' human rights and coordinating migration policies across countries. The topic of human rights is more prevalent thus we consider this first in more detail and then 
undertake our analysis of determining to what extent these salient themes are reflected in national migration legislation.

\section{CSM Theme I: Migrants' Human Rights}

Although South-North movements involve larger economic gaps between sending and receiving states, migration between CSM Member States is primarily among countries of the 'Global South'. Nonetheless, there are remarkable economic differences between Bolivia and Argentina, for example. High levels of intraregional migration areas mean that one state may have nationals from neighbouring areas, and vice versa. Securing a non-discriminatory treatment for its nationals, regardless of place, explains the interest of each country to agree upon a set of common rules. This is to avoid ill-treatment that South American nationals have reported to have receiving in, for example, Europe and North America.

As evident in the documents analysed, the CSM attendees consider migrant rights as a critical focal point of policy discussion and aims. Defending migrant human rights was a main pillar of why the CSM was founded as an RCP and has continuously permeated discourse. They were fundamental in the 2010 South American Human Development Plan for Migration (PSDHM using its Spanish acronym), a document containing the national governments' shared principles that demonstrate a mutual position on migration governance. As Acosta and Freier (2018) argue, the incorporation of human rights in the migration discussion is an effect of three factors: the end of dictatorships and their abuse; the rise in relevance of migration associated with large emigration flows following economic crises; and adding more social aspects to the heretofore predominantly economic-focused regionalisation processes.

Since the approval of the PSDHM in 2009, human rights have been specified as a permanent topic of interest. Every formal written declaration includes numerous mentions of 
promoting, extending and guaranteeing rights to migrants and their families, with special reference to women and children (CSM 2010a). Rights tend to be clustered around freedom of movement, social (inclusion) and economic (labour) rights. This is apparent throughout all the declarations up to present: at the 2017 Conference in Montevideo, CSM Members requested the Global Compact on Migration to consider a Global Framework of Human Rights Protection for all migrants and their families, based on existent Inter-American Human Rights instruments.

Focusing on rights is a practical CSM central theme since human rights agreements already exist regionally and globally (Mármora 2010). As stated in the Declaration of Principles from 2010, the CSM is extremely specific in defining human rights. CSM aims to extend these rights regardless of 'origin, nationality, gender, ethnicity, age, administrative migratory status, or any other cause of discrimination according to the existing international treaties over the subject, to allow the free mobility of South American female and male citizens' (CSM 2010b). Nonetheless, we find that this specificity and language does not continue fluidly thereafter. There is a recognition among South American states that migration is a result of the inequities and asymmetries among them, as well as between them and other countries. The states not only recognize the right to migrate and return, but also the right not to migrate. Here it is the state's responsibility to create the necessary conditions to 'prevent' its citizens from migrating (Mármora 2002; CSM 2010b).

During our analysis of the CSM documents, we found a weak focus on individuals and a stronger one on what a state can do to influence its citizens' decisions. Regional cooperation reflects a continued emphasis on migration policies aimed not only to assist regional and subregional integration, but also to uphold and encourage the implementation of international standards and accords. CSM participant states have repeatedly committed to providing protection 
not only for economic or labour migrants, but also for refugees. They draw on existing agreements, such as the 1951 Geneva Convention, the 1954 Caracas Convention on Diplomatic Asylum, the 1984 Cartagena Declaration on Refugees, and the Mexico Plan of Action of 2004. These promises further demonstrate the region's commitment — at least on paper — to extending rights to all types of migrants. The recognition of rights, however, continues to be dependent on each state's unilateral decisions. Despite human rights being such a prevalent CMS topic, the language around it is not uniform and the conference takes an impersonal top-down approach. Human rights of migrants and families are referred to, for instance, as the 'treatment of persons', 'nationals', 'the migrant person', or legally, such as 'the migrant person as a subject to the law', implying a subject that receives protection based on existence within the legal jurisdiction of a state.

\section{CSM Theme II: Inter-Country Migration Policy Coordination}

There appears to be an unstated, and non-institutionalized, link between the regionallevel accords towards coordinating ('harmonizing') migration policies among states. Since RCPs are non-binding, it is not their goal to define country-level migration policies, but rather to discuss success and failure of such policies. Nonetheless, the knowledge-sharing process leads nations to form ambitious accords at the CSM. Topics were set at the first CSM in 2000, then drafted into the Action Plan, approved in 2002, which proposes how to achieve regional migratory objectives. In 2010, two documents were signed: the Declaration of Migration Principles and Guidelines, as well as the South American Plan for the Human Development of Migrants. These accords are continually mentioned in all CSMs following their adoption. This became evident to us during the thematic analysis of CSM discussion and final documents because the topic of inter-country migration policy coordination is not directly addressed. Instead of attempting to encourage the implementation of non-binding agreements, policy coordination 
appears as an assumed line throughout, since it is written as an objective of the conference.

Given that we have found a regional-level agreement at the CSM that human rights are a priority and there is an existent aim for policy harmonisation, how do these salient themes relate to national-level policies? As the next section demonstrates, there have been changes in migrationrelated legislation in almost all of the South American countries since the CSM began in the year 2000. States have incorporated the notion of human rights into their migration laws from two positions: a more restrictive or more expansive perspective. We provide examples of both, as well as the grey area between, in order to discuss the possible advances and limits of this Regional Consultative Process.

\section{NATIONAL MIGRATION LAWS IN SOUTH AMERICA}

Except for Chile and Suriname, all countries in South America have changed their migration laws since 2000. The former still uses a law from 1975-although as of 2018, the Chilean Parliament is discussing new legislation-while the latter has never had migration legislation. Of the remaining countries, Argentina, Uruguay and Venezuela changed their main migration laws between 2000 and 2009. Bolivia, Colombia and Guyana developed new laws between 2011 and 2013, whereas Brazil, Ecuador, Paraguay and Peru modified their migration laws in 2016 and 2017 (MILEX 2018). While all have embraced a human rights approach to migration, the language used to capture what is understood as 'migrant rights' varies between countries. Furthermore, within countries throughout the region, written laws can greatly vary from actual implementation (Acosta and Freier 2015).

Even though the protection of certain types of migrants, namely asylum seekers, has been recognized since the late 1940s in South America, incorporating human rights vocabulary in migration legislation at the national level is more recent. Previously, this terminology was all but 
(unsurprisingly) non-existent in the laws from dictatorial times. Neither Argentina's Ley Videla of 1981, nor Chile's DL 1094 of 1975 even mentions migrants' rights. These are two clear examples of migration-related laws developed within a context of national security, positioning the foreigner as an enemy (Doña and Mullan 2014; Lara Escalona 2014). After dictatorial governments and political transitions had plagued South America up to the early 1990s, we find that these states then legally recognized that foreigners were not enemies and deserved certain rights. Foreigners holding just as many rights as nationals is not a new trend in the region since this was common practice in previous centuries (Acosta 2018).

More recently in Colombia and Ecuador (and Venezuela up until the early 2000s), constitutional rights again gave foreign residents within the state the same rights as nationals. While this is more open than preceding authoritarian decades, it represents a more restrictive approach as compared to the debates taking place at the CSM during this period, as well as compared to the rights expressed in the United Nations Migrants' Rights Convention. This more restrictive approach to migrants' rights continues up to some of the latest legislation, such as Colombia's Law 1,465 of 2011, Brazil's Law 13,445 of 2017, and the legislative proposal being discussed by the Chilean Congress as of mid-2018 (MILEX 2018).

A more expansive approach to migrants' rights is present in the Argentinean law 25,871 of 2003/2010, as well as in Bolivia's Law 370 of 2013, and Ecuador's 2017 Organic Law of Human Mobility (MILEX 2018). In these laws, the right to migrate is a human right. Thus, it is not that foreigners have in-country rights due to constitutional mandates, but rather individuals possess a human right to move to or from the country. These states not only follow the United Nations Migrants' Rights Convention, but also incorporate the 1948 Human Rights Convention, in which Article 13.2 states that all people have the right to leave their country and return to it 
and that this right cannot be infringed upon. This lies at the core of the arguments on the freedom of mobility that governments discuss at the CSM. This Article is also relevant for other regional agreements such as MERCOSUR's Residence Agreement and UNASUR's proposed South American citizenship.

Even though the spirit of these legislation is expansive in terms of rights, its application depends on local political dynamics. Argentina, for example, has gone from being a 'pioneer' in terms of migrants' rights to attempting to restrict migration in 2017 (with Decree 70/2017). Although local Argentine courts overruled this attempt in early 2018, its intention was to contradict the 2004 law protecting migrants' rights (Cerrutti and Parrado 2015; Romero and Politi 2017).

Contrary to protecting rights, some aspects of the Decree broke basic judicial guarantees in the American Convention on Human Rights as well as risked breaching the Inter-American Court on Human Rights' jurisprudence (Acosta and Brumat 2017). Amid debates over the new migration law in Chile, the country's Undersecretary of Interior has publicly expressed the view that the government does not consider migration as a right in itself (Ferrer 2018); rather, echoing the language of the 2018 Global Compact on Migration, Chile is focusing on 'safe, orderly and regular migration' whilst introducing restrictions and tightening migration control (Acosta et al. 2018). In 2018, the President of Bolivia, Evo Morales, also considered making the 2013 Bolivian law more restrictive. In the first two cases, governments have shifted from being left-leaning to more right-leaning; in Bolivia, Morales has experienced heightened opposition to his presidency. While it is not possible to assume causality in the relationship between participating in the CSM and more human-rights based approaches to migration legislation, we have found that there is some harmonisation between the regional and the national level albeit strongly mediated by 
domestic politics.

\section{CONCLUSION}

This chapter examined national and regional migration governance, as well as the extent to which the two reflect one another, in South America from 2000 to 2017. Through thematic analysis, we first identified the most salient topics from 17 years of the CSM, which were ensuring migrants' human rights and inter-country migration policy coordination amongst the 12 Member States. Although participants also discuss global accords, CSM meetings have resulted in their own (non-binding) agreements and continually show strong support for other regional efforts, particularly regarding regional or subregional integration and South American citizenship. Analysing the CSM shows that instead of working at the intermediate level between global and national scales, this RCP takes its regional position within migration governance to further support regional integration. The prioritisation and repetitiveness of select topics, as well as the language used around these, more closely reflect regional themes than global issues. These seem to be similar to Latin American regionalism in the sense that actors participate in a variety of regional organisations characterized by overlapping memberships, complementing (and at times competing) political, economic and social agendas (Bianculli 2016; Börzel and Risse 2016).

Taking the most prominent CSM themes, we also analysed how they compare to national migration laws that governments have adopted over the same period. The CSM discussion and aims are not uniformly reflected in national-level migration laws. We find a lack of a systematic approach to encouraging states to implement accords and priorities from the CSM. Despite the predominance of human rights in official declarations, we find that Member States have reproduced their national understanding of it in various ways. From 2000 to 2017, changes in 
migration laws throughout the region have moved toward providing migrants the same rights as nationals - comparatively, a more restrictive approach — instead of considering migration a right in itself, which we consider the most expansive approach. Political change at the national level has hindered greater expansion of these rights. As South America has moved away from the leftist governments of the early 2000s to more conservative governments (in Argentina, Brazil, Chile, Colombia, Paraguay and Peru), expanding migrants' rights is unlikely to occur (see Chapter 4). An example of what is to come was demonstrated in April 2018 when all South American states with conservative governments halted their participation in UNASUR, thus freezing their support for the South American citizenship proposal.

\section{ACKNOWLEDGEMENTS}

We extend our gratitude to the Centro de Estudios del Conflicto y Cohesión Social, Chile (Centro CONICYT/FONDAP/15130009) for research and travel support. We also thank the editors Andrew Geddes, Marcia Vera Espinoza, Leila Hadj-Abdou, and Leiza Brumat - of this volume for their extensive comments and dedication.

\section{REFERENCES}

Acosta, D. (2016), 'Free Movement in South America: The Emergence of an Alternative Model?', Migration Information Source, Migration Policy Institute

Acosta, D. (2018), The National versus the Foreigner in South America: 200 Years of Migration and Citizenship Law, Cambridge: Cambridge University Press.

Acosta, D. and L. Brumat (2017), ‘Argentina's restrictive turn on migration: Trump's first imitator in the Americas?', Migration Policy Centre, European University Institute.

Acosta, D. and L. F. Freier (2015), 'Turning the Immigration Policy Paradox Upside Down? 
Populist Liberalism and Discursive Gaps in South America', International Migration Review, 49 (3), 659-696.

Acosta, D. and L. F. Freier (2018), 'Regional Governance of Migration in South America', in A. Triandafyllidou (ed.), Handbook of Migration and Globalisation, Cheltenham: Edward Elgar Publishing.

Acosta, D., M. Vera-Espinoza, and L. Brumat (2018), 'The New Chilean Government and its Shifting Attitudes on Migration Governance', Migration Policy Centre, European University Institute.

Betts, A. and L. Kainz (2017), 'The History of Global Migration Governance', Working Paper Series No. 122, Refugee Studies Centre, University of Oxford.

Bianculli, A. C. (2016), 'Latin America', in T. A. Börzel and T. Risse (eds), The Oxford Handbook of Comparative Regionalism, Oxford: Oxford University Press, pp. 155-171.

Börzel, T. A. (2016), ‘Theorizing Regionalism: Cooperation, Integration, and Governance’, in T. A. Börzel and T. Risse (eds), The Oxford Handbook of Comparative Regionalism, Oxford: Oxford University Press, pp. 41-63.

Börzel, T. A. and T. Risse (2016), 'Introduction: Framerwork of the Handbook and Conceptual Clarifications', in T. A. Börzel and T. Risse (eds), The Oxford Handbook of Comparative Regionalism, Oxford: Oxford University Press, pp. 3-15.

Boswell, C. (2007), 'Migration Control in Europe After 9/11: Explaining the Absence of Securitization', Journal of Common Market Studies, 45 (3), 589-610.

Bowen, G. A. (2009) 'Document Analysis as a Qualitative Research Method', Qualitative Research Journal, 9 (2), 27-40.

Briceño-Ruiz J. and A. Ribeiro Hofmann (2015), 'Post-hegemonic Regionalism, UNASUR, and 
the Reconfiguration of Regional Cooperation in South America', Canadian Journal of Latin American and Caribbean Studies, 40 (1), 48-62.

Campillo-Carrete, B. (2013), 'South-South Migration: A Review of the Literature', ISS Working Paper Series, 570, 1-98.

Cerrutti, M. and E. Parrado (2015), 'Intraregional Migration in South America: Trends and a Research Agenda', Annual Review of Sociology, 41, 399-421.

Constant, A. F., O. Nottmeyer, and K. F. Zimmermann (2013), 'The Economics of Circular Migration', in A. F. Constant and K. F. Zimmermann (eds), International Handbook on the Economics of Migration, Cheltenham, UK and Northhampton, MA, USA: Edward Elgar Publishing, pp. 55-74.

CSM (2010a), Plan Sudamericano de Desarrollo Humano de las Migraciones, Contexto y Perspectivas.

CSM (2010b), Declaration of Migration Principles and Overall Guidelines of the SouthAmerican Conference on Migration, www.csm-osumi.org.

CSM-OSUMI (2017), Conferencia Suramericana sobre Migraciones - Observatorio Suramericano sobre Migraciones, $\underline{\text { www.csm-osumi.org. }}$

Doña Reveco, C. (2018), 'Amid Record Numbers of Arrivals, Chile Turns Rightward on Immigration', Migration Information Source, Migration Policy Institute.

Doña Reveco, C. and B. Mullan (2014), 'Migration Policy and Development in Chile', International Migration, 52 (5), 1-14.

Domenech, E. (2007), 'La agenda global sobre migraciones internacionales: la escena sudamericana', Novamerica, 115, 44-49.

Esthimer, M. (2016), 'Protecting the Forcibly Displaced: Latin America's Evolving Refugee and 
Asylum Framework', Migration Information Source, Migration Policy Institute.

Estupiñán, M. L. (2016), 'La Gestión Migratoria para la Gobernanza Global en Sudamérica. Apuntes Críticos', in A. Canales (ed.), Debates Contemporáneos sobre Migración Una Mirada desde América Latina, Mexico: MA Porrua, pp. 123-159.

Fereday, J. and E. Muir-Cochrane (2006), 'Demonstrating Rigor Using Thematic Analysis: A Hybrid Approach of Inductive and Deductive Coding and Theme Development', International Journal of Qualitative Methods, 5 (1), 1-11.

Ferrer, C. (2018), 'Ubilla niega que proyecto de migración sea racista: "Los países tienen derecho a decidir criterios de ingreso", EMOL, 15 April 2018.

GCIM, Global Commission on International Migration (2004), 'Possible Steps Towards an International Regime for Mobility and Security', Global Migration Perspectives, No. 8.

Geiger, M. and A. Pécoud (2014), 'International Organisations and the Politics of Migration', Journal of Ethnic and Migration Studies, 40 (6), 865-887.

Gurrieri, J. (2005), 'El proceso consultivo en América del Sur: La Conferencia Sudamericana sobre Migraciones', presented during a UN Expert Group Meeting on International Migration and Development in Latin America and the Caribbean. United Nations, Mexico. Hafner-Burton, E. M. (2012), 'International Regimes for Human Rights', Annual Review of Political Science, 15 (1), 265-286.

Hampshire, J. (2013), The Politics of Immigration: Contradictions of the Liberal State, Cambridge: Polity Press.

Hansen, R. (2010), ‘An Assessment of Principal Regional Consultative Processes on Migration’, IOM Migration Research Series, No. 38, International Organization for Migration, Geneva. Harns, C. (2013), 'Regional Inter-State Consultation Mechanisms on Migration: Approaches, 
Recent Activities and Implications for Global Governance of Migration', IOM Migration Research Series, No. 45, International Organization for Migration, Geneva.

Heisler, M. O. (1992), 'Migration, International Relations and the New Europe: Theoretical Perspectives from Institutional Political Sociology’, International Migration Review, 26 (2), 596-622.

Hollifield, J. F. (1992), 'Migration and International Relations: Cooperation and Control in the European Community', International Migration Review, 26 (2), 568-595.

Hollifield, J. F. (2000), 'Migration and the 'New' International Order: The Missing Regime', in A. Ghosh (ed.), Managing Migration: Time for a New International Regime?, Oxford: Oxford University Press, pp. 75-109.

Hollifield, J. F., P. L. Martin, and P. M. Orrenius (eds) (2014), A Global Perspective: Controlling Immigration, 3rd Edition, Stanford, CA: Stanford University Press.

Hugo, G. (2013), 'What We Know About Circular Migration and Enhanced Mobility', MPI Policy Brief 7, September, Migration Policy Institute, New York.

IOM (2003), 'Managing Migration: Challenges and Response for People on the Move', World Migration Report 2003, International Organization for Migration, Geneva.

IOM (2018), Regional Consultative Processes on Migration. www.iom.int/regional-consultativeprocesses-migration.

Klein Solomon, M. (2005), 'International Migration Management through Inter-State Consultation Mechanisms', International Organization for Migration, Geneva.

Klekowski von Koppenfels, A. (2001), 'The Role of Regional Consultative Processes in Managing International Migration', IOM Migration Research Series, No. 3, International Organization for Migration, Geneva. 
Laczko, F., and T. Brian (2013), 'North-South Migration: A Different Look at the Migration and Development Debate', Technical Report June-July, International Organization for Migration, Geneva.

Lara Escalona, M. D. (2014), 'Evolución de la legislación migratoria en Chile claves para una lectura (1824-2013)', Revista de Historia del Derecho, 47, 59-104.

Lavenex, S., F. Jurje, T. E. Givens, and R. Buchanan (2016), 'Regional Migration Governance', in T. A. Börzel and T. Risse (eds), The Oxford Handbook of Comparative Regionalism, Oxford: Oxford University Press, pp. 458-481.

Mármora, L. (2002), Las Políticas de las Migraciones Internacionales, Editorial Paidos, Buenos Aires.

Mármora, L. (2010), 'Modelos de Gobernabilidad Migratoria: La perspectiva política en América del Sur', Revista Interdisciplinar da Mobilidade Humana, 35, 71-92.

Martínez, J. and C. Orrego (2016), Nuevas tendencias y dinámicas migratorias en América Latina y el Caribe, Santiago, Chile: CEPAL/CELADE.

Martínez, J. and M. F. Stang (2006), 'El tratamiento migratorio en los espacios de integración sudamericana', Papeles De Población, 12 (48), 77-106.

MILEX (2018), Database of Migration Legislation in the Americas, Organization of American States (OAS), www.migracionoea.org/index.php/en/milex-en.html.

NATLEX (2018), Database of National Labour, Social Security and Related Human Rights Legislation, International Labour Organization www.ilo.org/dyn/natlex/natlex4.home?p_lang=en.

O’Neil, K. (2003), 'Discussion on Migration and Development: Using Remittances and Circular Migration as Drivers for Development', Report, Migration Policy Institute, Washington 
D.C.

Pellegrino, A. (2007), 'Immigration et émigration en Amérique du Sud', Revue Hommes et migrations, 1270, 102-113.

Pevehouse, J. C. (2016), 'Regional Human Rights and Democracy Governance', in T. A. Börzel and T. Risse (eds), The Oxford Handbook of Comparative Regionalism, Oxford: Oxford University Press, pp. 487-505.

Ramírez, J. P. (2016), Hacia el Sur. La Construcción de la Ciudadanía Suramericana y la Movilidad Intrarregional, Quito, Ecuador: Centro Estratégico Latinoamericano de Geopolítica.

Ratha, D. and W. Shaw (2007), 'South-South Migration and Remittances', World Bank Working Paper No. 102, World Bank, Washington D.C.

Romero, S. and D. Politi (2017), 'Argentina's Trump-Like Immigration Order Rattles South America', The New York Times.

Söderbaum, F. (2016), Rethinking Regionalism, London: Palgrave Macmillan.

Tamas, K. and J. Palme (2006), 'Transnational Approaches to Reforming Migration Regimes', in K. Tamas and J. Palme (eds), Globalizing Migration Regimes: New Challenges to Transnational Cooperation, Aldershot, UK: Ashgate Publishing, pp. 3-22.

UNASUR 2018. 'UNASUR apuesta a la construcción de la ciudadanía suramericana', www.unasursg.org/es/node/118.

UNDESA (2017), 'International Migrant Stock: The 2017 Revision', United Nations Department of Economic and Social Affairs, Population Division, www.un.org/en/development/desa/population/migration/data/estimates2/estimates 17.sht $\underline{\mathrm{ml}}$. 
United Nations (2005), 'The International Convention on Migrant Workers and its Committee', Office of the United Nations High Commissioner for Human Rights, Geneva.

\section{ENDNOTES}

${ }^{1}$ The acronym CSM, Conferencia Suramericana sobre Migraciones, follows the original language used on the official website (csm-osumi.org) and in conference declarations; note that others (for instance, Hansen 2010) use the acronym SACM.

${ }^{2}$ Brazilian laws are analysed from www4.planalto.gov.br/legislacao.

${ }^{3}$ South American countries generally fall into the 'South' or 'Global South' classification as developing countries. The exception is Chile after joining the OECD in 2010, thus by some scales is considered a developed country (the 'North' or 'Global North') (Laczko and Brian 2013). This broad classification fails to capture any subtle power differences within regions, which indeed exist in South America, yet are beyond this paper's scope.

${ }^{4}$ There is no language barrier between nine of the 12 country participants, with Brazil, Guyana and Suriname as exceptions.

${ }^{5}$ In the 2003 meeting in Uruguay, the countries agreed to take steps to institutionalize the South American Conference; institutionalisation resulted in forming the Plan of Action, approved in 2010, then defining a set of procedures in 2012, which were revisited in 2014 and 2015, then approved in 2016.

${ }^{6}$ The presidency receives support from a focal point in each country, from the IOM, which acts as the permanent technical secretary, as well as from la Troika, which according to the Rules of Procedure, Article 7, is composed of the countries that hold the current, former and future presidency. Chile and Uruguay have held the presidency three times, whereas Argentina, Bolivia, 
Ecuador and Paraguay have each held it twice. Brazil, Colombia and Venezuela have each performed this function once. For details on the president's responsibilities, see the Rules of Procedure, Article 6, approved in Paraguay in 2016.

${ }^{7}$ In their original language acronyms, CAN stands for the Andean Community of Nations, MERCOSUR is the Southern Common Market, while UNASUR is the Union of South American Nations.

${ }^{8}$ Original statement: 'a reunir, mantener y compartir experiencias exitosas en política y gestión migratoria' (CSM-OSUMI 2017). 